\begin{abstract}
KS. HENRYK STAWNIAK SDB
Wydział Prawa Kanonicznego

Uniwersytetu Kardynała Stefana Wyszyńskiego w Warszawie

ORCID: 0000-0003-0708-0907
\end{abstract}

\title{
FORMA ZAWARCIA MAŁŻEŃSTWA MIESZANEGO
}

Treść: Wstęp. - 1. Małżeństwa mieszane i im podobne oraz podmioty związane tymi przepisami. - 2. Wymogi dotyczące małżeństw mieszanych w kanonie 1125 KPK. - 3. Dyspensowanie od zachowania formy kanonicznej. - 4. Asystencja kapłana, gdy jedna strona przynależy do wspólnoty wschodniej, przy formie zwyczajnej i nadzwyczajnej. - 5. Dyskusje wokół waloru prawnego formy kanonicznej i jej funkcji w kontekście aktu formalnego wystąpienia z Kościoła. - Zakończenie.

\section{Wstęp}

Aktualne uwarunkowania społeczne, nasilająca się migracja ludności, ale również fakt zaniedbania spraw wiary, akty formalnego wystąpienia $\mathrm{z}$ Kościoła oraz fakt liberalnej koncepcji wolności powodują, iż coraz częściej pojawiają się kwestie związane z zastosowaniem formy kanonicznej zawarcia małżeństwa, w tym mieszanego. W tym kontekście nie można nie zauważyć modyfikacji norm dotyczących formy zawarcia małżeństwa dokonanej przez papieża Franciszka ${ }^{1}$ w roku 2016 i wcześniej zmian dokonanych przez papieża Benedykta XVI²

\footnotetext{
${ }^{1}$ Franciscus, Litterae Apostolicae motu proprio datae quibus nonnullae normae Codicis Iuris Canonici immutantur, AAS 107 (2016), s. 603.

${ }^{2}$ Benedictus XVI, Litterae Apostolicae motu proprio datae Omnium in mentem quedam in Codice Iuris Canonici immutantur, AAS 102(2010), s. 8-10.
} 
w roku 2009. Wspomniane dokumenty dookreśliły jakie podmioty wiąże pojęcie małżeństw mieszanych i kto może być dyspensowany od zachowania formy kanonicznej oraz zwróciły uwagę na świadka kwalifikowanego przy małżeństwie strony przynależącej do wspólnoty wschodniej zawieranym w formie zwyczajnej i nadzwyczajnej. Chociaż zwykle racje natury eklezjalnej, społecznej i prawnej przemawiają za potrzebą stosowania określonej formy zawarcia małżeństwa, to jednak wysuwa się współcześnie zastrzeżenia, czy wymóg formy do ważności (ad validitatem) małżeństwa winien być utrzymany?, skoro porządek prawny zdaje się wystarczająco zaradza potrzebom publicznego charakteru i pewności prawnej, tak przez formę zawarcia małżeństwa, jak i jego cywilną rejestrację. Ta wątpliwość staje się ewidentna, gdy forma kanoniczna zawarcia małżeństwa wiąże osoby, które przez formalny akt wystąpiły z Kościoła. Zarysowane powyżej kwestie będą przedmiotem niniejszych rozważań.

\section{Małżeństwa mieszane i im podobne oraz podmioty związane tymi przepisami}

Określenie 'małżeństwo mieszane' domaga się doprecyzowania terminologicznego i zaakcentowania zmian, które dokonały się w ostatnim czasie. Otóż kan. 1124 KPK przed 2009 rokiem³ ${ }^{3}$ stanowił, że jest nim małżeństwo między dwiema osobami ochrzczonymi, z których jedna została ochrzczona w Kościele katolickim lub po chrzcie została do niego przyjęta i formalnym aktem od niego się nie odłączyła, druga zaś należy do Kościoła lub wspólnoty kościelnej nie mającej pełnej łączności z Kościołem katolickim. Natomiast po tej dacie, z uwagi na m.p. Omnium in mentem, z cytowanej normy zostały usunięte słowa: „i formalnym aktem od niego się nie odłączyła”. Ta zmiana treści kan. 1124 obowiązująca od 8 kwietnia 2010 roku oznacza, że katolik mimo formalnego odłączenia się od Kościoła katolickiego pozostaje katolikiem i zawierane przez niego małżeństwo z osobą, która należy do Kościoła lub wspólnoty kościelnej nie mającej pełnej łączności

\footnotetext{
${ }^{3}$ Istotną zmianę wprowadziło m.p. Omnium in mentem..., por. AAS 102(2010), s. 8-10; przekład polski 'L’Osservatore Romano', wyd. polskie 31(2010) nr 5, s.13-14.
} 
z Kościołem katolickim jest traktowane jako małżeństwo mieszane $\mathrm{w}$ ścisłym tego słowa znaczeniu. Usunięcie $\mathrm{z}$ kanonu klauzulę actus formalis defectionis ab Ecclesia Catholica tym samym poszerza krąg osób, które są związane przepisami o małżeństwach mieszanych ${ }^{4}$.

Podobnymi do małżeństw mieszanych w ścisłym tego słowa znaczeniu są małżeństwa mieszane w szerokim znaczeniu. Jest to przede wszystkim małżeństwo katolika z osobą nieochrzczoną po myśli kan. $1086 \$ 1$, zachodzi wówczas przeszkoda różności religii (disparitas cultus). Zakres tej przeszkody również uległ zmianie bowiem osoby, które wystąpiły z Kościoła katolickiego formalnym aktem nie mogą ważnie zawrzeć małżeństwa $\mathrm{z}$ osobą nieochrzczoną̧. Było to możliwe przed motu proprio papieża Benedykta XVI, gdyż w świetle ówczesnego kodeksu nie było przeszkody różności religii, gdy osoba formalnym aktem wystąpiła z Kościoła i zawierała małżeństwo z nieochrzczoną. Wymogi związane z zawarciem małżeństwa mieszanego w szerokim tego słowa znaczeniu dotyczą też małżeństwa z osobą, która porzuciła wiarę katolicką (kan. 1071, \$1, 4, i \$2). W tym miejscu należy jeszcze dodać, że Instrukcja Episkopatu Polski z $1986^{6}$ r., ze względów praktycznych - $\mathrm{w}$ dziale Małżeństwa mieszane i im podobne - klasyfikuje następujące przypadki małżeństw: katolika z nieochrzczonymi, z niekatolikami ochrzczonymi, z niepraktykującymi oraz z osobami, które formalnym aktem odstąpiły z Kościoła katolickiego.

Treści dookreślające pojęcie małżeństwa mieszanego w prawie kanonicznym już pozwalają orientować się o podmiotach podlegających przepisom w tym względzie. Należy jednak dopowiedzieć, że strona nieochrzczona lub akatolicka wprawdzie nie podlega wprost

\footnotetext{
${ }^{4}$ Por. Kodeks Prawa Kanonicznego. Komentarz, red. P. Majer, Kraków 2011, [dalej: Komentarz], s. 848.

${ }^{5}$ Por. tamże, s. 803-805; U. NowickA, Przeszkoda różności religii, w: Przeszkody małżeńskie w prawie kanonicznym, pod red. W. Góralskiego, Wydawnictwo UKSW, Warszawa 2016, s. 221, przypis 120.

${ }^{6}$ Konferencja EPISKopAtu Polski, Instrukcja Episkopatu Polski o przygotowaniu do zawarcia małżeństwa w Kościele katolickim, (5.09.1986), (odtąd Instrukcja z 1986), w: Papieska Akademia Teologiczna, Małżeństwa mieszane, red. Z.J. Kijas, Kraków 2000, nr 71.
} 
normom Kościoła katolickiego, to jednak z uwagi na zamiar małżeństwa z katolikiem, też pośrednio ją wiążą. Wskazują na to kan. 11 i 1059 KPK. Ten ostatni stanowi: Małżeństwo katolików, chociażby tylko jedna strona była katolicka ${ }^{7}$, podlega nie tylko prawu Bożemu, lecz także kanonicznemu, z zachowaniem kompetencji władzy państwowej odnośnie do czysto cywilnych skutków tegoż małżeństwa. Zatem druga strona, która jest katolikiem, bądź ochrzczonym niekatolikiem, bądź osobą nieochrzczoną, podlega prawu kościelnemu. Takie myślenie potwierdzają też kanony $1086 \$ 2$, 1117, 1124 i 1127 KPK. Należy jednak zauważyć, że przepisy o małżeństwach mieszanych wiążą osoby, o ile w momencie zawierania małżeństwa, jedna ze stron jest rzeczywiście katolikiem. W tym kontekście należało postawić pytanie: co oznaczało, że osoba formalnym aktem odłączyła się od Kościoła katolickiego i przestaje być katolikiem, którego nie obligują przepisy o małżeństwach mieszanych? Instrukcja z 1986 tak oznajmia: „Przez osoby, które formalnym aktem odstąpiły od Kościoła, należy rozumieć tych, którzy dokonali odstępstwa bądź na piśmie, bądź wobec dwóch świadków, bądź ujawnili swoje faktyczne wystąpienie z Kościoła wobec przedstawiciela władzy kościelnej, o ile takie stanowisko zewnętrzne pokrywa się z ich przekonaniem wewnętrznym" (nr 72,3). Nie powodowało takich skutków prawnych wychowanie poza Kościołem nawet od dzieciństwa, nieuporządkowane życie moralne, publiczne negowanie zasad katolickich i brak praktyk katolickich ${ }^{8}$. Nie wystarczał też formalny akt wystąpienia, podpisany wobec władzy cywilnej, z uwagi na finanse (Kirchensteuer), jak to ma miejsce w Niemczech i Austrii. Formalny akt odłączenia nie był tym samym, co notoryczne porzucenie wiary katolickiej po myśli kan. 751 w łączności z punktem $4 \$ 1$ kan. 1071 i 1364, chociaż w pewnym sensie tych ostatnich można nazwać akatolikami.

\footnotetext{
${ }^{7}$ Tekst promulgowany zawierał najpierw określenie: etsi una tantum sit baptizata, który potem zmieniono na: etsi una tantum sit catholica. AAS 75(1983), s. 324.

${ }^{8}$ Por. Z. Grocholewski, I matrimoni misti, w: Matrimonio canonico fra tradizione e rinnovamento, Bologna 1991, s. 266n.
} 
Z dotychczasowej analizy wynika, że by można mówić o obligatoryjności przepisów o małżeństwach mieszanych winna być przynależność do Kościoła katolickiego jednej ze stron, a jeżeli żadna ze stron nie jest katolikiem, nie podlega tym przepisom. Po m.p. Omnium in mentem, wyraźnie też należy zaznaczyć, że prawodawca nie wyłączył, a raczej ponownie włączył, do zakresu małżeństw mieszanych osoby, które formalnym aktem odłączyły się z Kościoła katolickiego. Sformułowania kanonów 1086, 1117 i 1124 KPK, które zawierały wspomnianą klauzulę, motywowane były względami wolności sumienia i ekumenizmem ${ }^{9}$. Klauzule te jednak powodowały wiele zamieszania w Kościele co do ważności niektórych małżeństw i tym samym przejrzystości i pewności prawa. Przede wszystkim zaś uświadomiono sobie, że formalny akt wystąpienia z Kościoła nie jest zdolny do wymazania ontologicznej przynależności do Chrystusa i Kościoła, jaka rodzi się w momencie chrztu ${ }^{10}$. Wola respektowania wolności sumienia osoby i ekumenizmu zderzyła się więc z prawdą ontologiczną. Decyzja papieża Benedykta XVI nie była łatwa, bo jak czyta się w jednym z opracowań ${ }^{11}$, „chodziło o wybór między dwoma dobrami. Każde z rozwiązań - tak kodeksowe, jak i obecne - można postrzegać i oceniać zarówno pozytywnie, jak i od zdecydowanie negatywnej strony. Zwolnienie osoby, która odłączyła się od Kościoła formalnym aktem z obowiązku zachowania formy kanonicznej wydaje się logiczne (...) Ale z drugiej strony owo wystąpienie z Kościoła katolickiego formalnym aktem nie może oznaczać nic innego jak tylko nową, specyficzną formę zerwania wiernego pełnej wspólnoty z Kościołem katolickim. Nie jest bowiem możliwe wyłączenie z Kościoła w sensie obiektywnym, ze względu na nieodwracalne ontologicznie skutki sakramentu chrztu św. Osoby ochrzczone w Kościele katolickim należą do tegoż Kościoła nie na

\footnotetext{
${ }_{9}^{9}$ Por. M. Al. Żurowski, Kanoniczne prawo matżeńskie Kościoła katolickiego, Katowice 1987, s. 356.

${ }^{10}$ Por. R. Wierzchanowski, Czy jeszcze katolik? Wystąpienie z Kościoła formalnym aktem, Warszawa 2017, s. 154.

${ }^{11}$ U. Now ICKA, Obowiązywalność kanonicznej formy zawarcia małżeństwa po motu proprio „Omnium in mentem” papieża Benedykta XVI, Prawo i Kościół 3(2011), s. 74 .
} 
mocy jakiejś formalności, zapisania się, które w każdym czasie może zostać odwołane (...) A skoro tak, to równie logiczne wydaje się, że formalne jedynie zerwanie wspólnoty z Kościołem nie powinno dawać możliwości nieegzekwowania jego praw”.

\section{Wymogi dotyczące małżeństw mieszanych w kanonie 1125 KPK $^{12}$}

Powyżej sygnalizowane akcenty ekumeniczne norm nie mogą przysłonić tego, że kościelny porządek prawny musi uwzględniać i opierać się na Bożym porządku, a ten na wiernych nakłada określone obowiązki. Wymagania pochodzące z prawa Bożego są interpretowane przez Kościół, są precyzowane w odpowiedniej formie w prawie kościelnym, w zależności od różnych okoliczności i czasu. Kościół może łagodzić przepisy, ale też są takie obowiązki, od których nie można się uwolnić, gdyż są treściowo w prawie Bożym. Znamienne jest stwierdzenie w tym względzie motu proprio Matrimonia mixta ${ }^{13}$, że chociaż Kościół wprowadza w poszczególnych wypadkach pewne złagodzenie dyscypliny kościelnej, to jednak nigdy nie może uwolnić strony katolickiej od obowiązku, jaki - zależnie od różnych okoliczności - nakłada prawo Boże, czyli porządek zbawienia ustanowiony przez Chrystusa. W tym kontekście problem porządku Bożego wiąże się z kwestią zachowania wiary, obowiązku ochrzczenia i wychowania potomstwa w Kościele katolickim według zasad kan. 1125 KPK. Wymieniony kanon, $\mathrm{z}$ uwagi na fakt zabronienia zawierania małżeństwa bez zezwolenia w kan. 1124, stanowi, że tego rodzaju zezwolenie ( $l i$ centia) może być udzielone, jeśli istnieje słuszna i rozumna przyczyna, oraz po spełnieniu warunków określonych dla strony katolickiej i akatolickiej ${ }^{14}$.

${ }^{12}$ Treść i literatura z artykułu: H. Stawniak, Małżeństwa mieszane, Ateneum Kapłańskie 148(2007), s. 1(587) s. 26-30 wraz ze współczesnymi uzupełnieniami.

${ }^{13}$ AAS 62(1970) s. 257-265; tekst polski Posoborowe Prawodawstwo Kościelne, zebrał i przetłumaczył E. Sztafrowski, Warszawa 1971, t. III, z. 2, nr 5232, s.10.

${ }^{14}$ Por. Komentarz, s. 849. 
Strona katolicka winna oświadczyć, czytamy w 1 punkcie kan. 1125, że jest gotowa odsunąć od siebie niebezpieczeństwo utraty wiary, jak również złożyć szczere przyrzeczenie, że uczyni wszystko, co w jej mocy, aby wszystkie dzieci zostały ochrzczone i wychowane w Kościele katolickim. To stwierdzenie, oparte słowo w słowo na Matrimonia mixta, zawiera praktycznie dwa zobowiązania, zachowania prawa Bożego w obowiązkach dotyczących wiary i wychowania. Pierwszy obowiązek dotyczący zachowania wiary jest kategoryczny i zależny tylko od dobrej woli strony katolickiej. Stąd winna ona odsunąć wszelkie bezpośrednie niebezpieczeństwo utraty wiary ${ }^{15}$. Drugi obowiązek jest związany z chrztem w Kościele katolickim i wychowaniem potomstwa w tym duchu. Wypełnienie tego obowiązku zależy nie tylko od zaangażowania i dobrej woli strony katolickiej, ale także od innych czynników małżeńskich i rodzinnych. Z tego ostatniego względu prawodawca domaga się przyrzeczenia, że 'uczyni wszystko, co w jej mocy’. Wśród tych czynników, od których zależy realizacja przyrzeczenia, jest druga strona - akatolik, który również ma prawo do dziecka i jego wychowania, ma swoje przekonania religijne, ma sumienie i cieszy się prawem wolności religijnej ${ }^{16}$.

Druga strona niekatolicka nie składa żadnych przyrzeczeń. Ma być poinformowana o składanych przyrzeczeniach strony katolickiej, tak aby rzeczywiście była świadoma treści przyrzeczenia i obowiązku strony katolickiej (2 punkt kan. 1125). W tej dyspozycji prawa wyraźnie widać intencję prawodawcy kościelnego opartą na soborowej zasadzie poszanowania sumienia i wolności religii, że nie wymaga się

\footnotetext{
${ }^{15}$ Por. G. DzIerżon, Ewolucja doktryny oraz dyscypliny dotyczących przeszkody 'różności religii' w kanonicznym porządku prawnym, Warszawa 2008, s. 316; T. Jakubiak, Prawno-liturgiczne aspekty zawierania małżeństw z osobami, które formalnym aktem wystapiły $z$ Kościoła, w: Kanoniczno-liturgiczne aspekty zawierania małżeństw mieszanych i im podobnych, red. U. Nowicka, Warszawa 2014, s. 52-54.

${ }^{16}$ Por. Z. Grocholewski, I matrimoni misti, s. 269; E. Gajda, Treść zobowiązań składanych przez katolika w celu uzyskania licencji na małeństwo mieszane, w: Plenitudo legis dilectio, red. A. Dębiński, E. Szczot, Lublin 2000, s. 277-282: D. Salachas, I matrimoni misti nel Codice latino e in quello delle Chiese Orientali cattoliche, w: I matrimoni misti, Città del Vaticano 1998, s. 67-69.
} 
niczego co byłoby sprzeczne z sumieniem i przekonaniami religijnymi akatolika. Nie ma więc po stronie akatolika, jak to było do r. 1970 przyrzeczenia o nie przeszkadzaniu w wypełnieniu zadań po stronie katolika, ale jest tylko informacją o tych zobowiązaniach. Godny podkreślenia jest akcent Dyrektorium w tej materii. Równocześnie trzeba stwierdzić, że strona niekatolicka może odczuwać podobne zobowiązanie ze względu na swe własne zaangażowanie chrześcijańskie. Należy więc zauważyć, że w Prawie kanonicznym nie wymaga się od drugiego partnera $\dot{z} a d n e j$, pisemnej czy ustnej obietnicy ${ }^{17}$.

Kanon 1126 KPK dopowiada, że odpowiednie normy dotyczące całej procedury związanej ze składaniem oświadczeń i przyrzeczeń oraz jak ma być powiadomiona strona niekatolicka ma ustalić Konferencja Episkopatu. Instrukcja z 1986 zawiera w numerach 83-88 takie właśnie przepisy. Z nich wynika, że obie strony podpisują oświadczenia i przyrzeczenia w 3 egzemplarzach. Gdyby strona niekatolicka wzbraniała się przed złożeniem podpisu, duszpasterz, o ile ma moralną pewność, że treść zobowiązań strony katolickiej dotarła do świadomości strony niekatolickiej, sam poświadcza o tym fakcie. Zaznacza jednak w prośbie o zezwolenie, że strona niekatolicka, będąc poinformowana o treści rękojmi drugiej strony, odmówiła potwierdzenia podpisem przekazania jej tej informacji (nr 85). Może się zdarzyć, że strona niekatolicka, przyjąwszy informację o rękojmiach strony katolickiej, wyraźnie oświadczy, że zrobi wszystko, by nie dopuścić do realizacji jej przyrzeczeń. Wówczas Instrukcja poleca duszpasterzowi wyjaśnić ze spokojem, że małżeństwo, ma być wspólnotą życia i miłości wobec Boga, który dla wierzących jest najwyższą wartością, dzieci zaś, które są darem Boga mają pogłębić ich wspólnotę i ją uszlachetnić, natomiast Kościół chce udoskonalić wszystkie wartości ludzkie i dlatego też zawiązującego się ogniska rodzinnego nie może wystawiać na sytuację konfliktową, zanim się ono ukształtowało (nr 86). Gdyby

\footnotetext{
${ }^{17}$ Papieska Rada ds. Jedności Chrześcijan, Dyrektorium w sprawie realizacji zasad i norm dotyczacych ekumenizmu (25.03.1993), Communio 16(1994) nr 151, [dalej: DE].
} 
te pouczenia nie przekonały strony akatolickiej, duszpasterz winien sprawę przedstawić ordynariuszowi miejsca.

Dotykamy tutaj bardzo złożonego i trudnego problemu dotyczącego potomstwa, jego chrztu i wychowania. Strona akatolicka może nie chcieć podpisać rękojmi, bo chce partycypować w zadaniach rodzicielskich ${ }^{18}$. Zresztą Kościoły i Wspólnoty 'mniejszościowe’ uważają, że w tych sprawach prawo kanoniczne dyskryminuje je, odmawiając równego prawa do wychowania dzieci ${ }^{19}$. Czy nie mają jednak racji? A przecież Konferencje Episkopatu Austrii, Węgier, Szwajcarii w ogóle nie żądają przyrzeczenia w tym względzie, Kanadyjska żąda przyrzeczenia dopiero po dyskusji na ten temat. Poinformowanie strony akatolickiej o oświadczeniach i przyrzeczeniach też ma różne formy lub wcale się jej nie określa. Na przykład Argentyńska Konferencja stanowi, że jeżeli niekatolik nie chce spotkać się z proboszczem, strona katolicka powinna poinformować go pisemnie o zobowiązaniach ${ }^{20}$.

Takie rozwiązanie odpowiada treści zalecenia Dyrektorium ekumenicznego. Stanowi on, że trzeba sugerować i popierać dyskusję, a także - jeśli to możliwe - decyzję podjętą przed zawarciem małżeństwa, na temat chrztu i katolickiego wychowania dzieci, które przyjdą na świat? Można odpowiedzieć, że są to zachęty do trudnych dyskusji i decyzji, przed ubieganiem się o zezwolenie na małżeństwo mieszane. Ich wynik może mieć wpływ na udzielenie licencji lub odmowę, gdyż w nich znajduje się lub nie 'słuszna i rozumna przyczyna' (nr 150).

Gdyby strona katolicka nie chciała dostosować się do wymogów kan. 1125 punkt 1 i odmówiła złożenia oświadczenia i przyrzeczenia,

\footnotetext{
${ }^{18}$ Por. A. Авате, Il matrimonio nella nuova legislazione canonica, Brescia 1985, s. 187; G.P. Montini, Le garanzie o 'cauzioni' nei matrimoni misti, Quaderni di Diritto Ecclesiale 5(1992), s. 290; G. DzIERżon, Problem konieczności wypełnienia warunków dotyczących stron umowy małżeńskiej określonych przez ustawodawstwo Kościoła Polskokatolickiego w przypadku zawierania małżeństwa mieszanego przez katolika w Kościele polskokatolickim, Ius Matrimoniale 25(2014), nr 4, s. 52-53.

${ }^{19}$ Por. S.C. NAPIóRKowski, Małżeństwa o różnej przynależności wyznaniowej. $Z$ prac podkomisji. w: Plenitudo legis dilectio..., s. 755-776.

${ }^{20}$ Por. J.T. Martin de Agar, Le competenze della Conferenza Episcopale: cc. 1126 e 1127 \$2, w: I matrimoni misti, Città del Vaticano 1998, s. 151.
} 
to w myśl zaleceń Instrukcji z 1986 r., duszpasterz powinien zaprzestać starania o zezwolenie na małżeństwo mieszane ( $\mathrm{nr} 87$ ).

Obok podpisania przez obie strony rękojmi, innym warunkiem do godziwości otrzymania zezwolenia na zawarcie małżeństwa mieszanego jest pouczenie obydwu stron - w myśl punktu 3, kan. 1125 o celach oraz istotnych przymiotach małżeństwa tj. jego jedności, nierozerwalności i sakramentalnej godności między ochrzczonymi, których nie może wykluczyć żadna ze stron ${ }^{21}$. Wśród celów i zadań małżeńskich jest zrodzenie i wychowanie potomstwa (kan. 1055 \$1). W odniesieniu do wychowania trzeba zaznaczyć, że wykluczeniem istotnego elementu małżeństwa byłoby nie tylko odrzucenie istnienia obowiązku wychowania, ale także, znaczące w małżeństwach mieszanych, wola odrzucenia wspólnego udziału obojga małżonków w wychowywaniu wspólnych dzieci, gdyby jedna ze stron zastrzegłaby to prawo wyłącznie dla siebie. Owe pouczenie jest też ważone w kontekście różnego od katolickiej pojmowania przez stronę niekatolicką teologii małżeństwa, zwłaszcza zagadnienie sakramentalności i nierozerwalności. Edukacja w tym względzie ma zapobiec symulacji małżeństwa, która stanowiłaby o jego nieważności (por. kan. $1101 \$ 2$ ). Warto też wspomnieć, że dialog międzywyznaniowy w tych właśnie punktach, o nierozerwalności i sakramentalności małżeństwa, ma też trudności w wypracowaniu wspólnego stanowiska ${ }^{22}$.

W związku z ubieganiem się o pozwolenie można postawić kilka pytań: kto jest uprawniony do wniesienia prośby o zezwolenie?; jaki jest wpływ zatajenia prawdy i przedstawienia fałszu na ważność licencji?; kto jest kompetentny do wydania zezwolenia oraz w jakiej formie ma być wydana? Nie wnikając w szczegóły ${ }^{23}$ można stwierdzić, że ów akt o charakterze administracyjnym nie musi mieć charakteru

\footnotetext{
${ }^{21}$ Por. też Instrukcja z 1986, nr 76.

${ }^{22}$ Por. np. Sprawozdanie końcowe Komisji naukowej Kościołów rzymskokatolickiego, luterańskiego i kalwińskiego za rok 1976, w: Papieska Akademia Teologiczna, Małżeństwa mieszane, Kraków 2000, s. 191-194.

${ }^{23}$ Szerokie omówienie tych kwestii znajduje się w publikacji: G. DzIERżon, Administracyjny charakter zezwolenia na zawarcie małżeństwa mieszanego, w: Ecclesia et status, red. A. Dębiński, K. Orzeszyna, M. Sitarz, Lublin 2005, s. 355-375.
} 
pisemnego i nie ma on wpływu unieważniającego, zwykle prosi o ten akt duszpasterz a kompetentnym do jego udzielenia jest ordynariusz miejsca.

Obowiązek ochrzczenia wszystkich dzieci w Kościele katolickim, podkreślany w cytowanym już kan. 1125, musi być także konfrontowany z kan. 1366, w którym stwierdza się, że rodzice lub ich zastępcy, którzy oddają dzieci do chrztu lub na wychowanie w religii niekatolickiej, powinni być ukarani cenzurą lub inną sprawiedliwą karą. Co oznacza oddanie na wychowanie? Czy rodzic katolik popełnia to przestępstwo żyjąc w małżeństwie mieszanym? Przez słowo „oddanie” użyte w kan. 1366 należy rozumieć zlecenie albo powierzenie dzieci jakiejś osobie lub instytucji w celu określonego wychowania, które jest sprzeczne z wychowaniem katolickim. Zlecenie to powinno być przyjęte przez zleceniodawcę, gdyż w przeciwnym wypadku czynność należy potraktować jako przestępstwo usiłowane. Wychowanie w religii akatolickiej polega zarówno na wychowaniu areligijnym, jak i religijnym, ale niekatolickim. Już motu proprio Matrimonia mixta stanowiło, że oddanie dziecka do chrztu szafarzowi akatolickiemu nie stanowi przestępstwa, gdy uczyniła to strona w małżeństwie mieszanym. Ten sam dokument zniósł także kary za akatolickie wychowanie dzieci w tych małżeństwach. Stąd też kan. 1366 musi być interpretowany z uwzględnieniem tradycji kanonicznej, czyli zgodnie z wymienionym wyżej dokumentem i dlatego też ze względu na prawa niekatolika strona katolicka, która nie może wypełnić przyrzeczenia i powierza swoje dzieci do chrztu lub na wychowanie w religii niekatolickiej nie popełnia przestępstwa ${ }^{24}$. Niemniej spoczywa na stronie katolickiej obowiązek dzielenia ze swymi dziećmi wiary katolickiej. Obowiązek ten trwa nadal, zwłaszcza zaś słowem i przykładem. Rodzic katolicki ma jednak uszanować wolność religijną i sumienie drugiego rodzica oraz będzie się troszczył o jedność i trwałość małżeństwa i zachowanie komunii rodzinnej. W ten sposób odrzuca się rodzicielską postawę indyferentyzmu, nacechowaną relatywizmem

\footnotetext{
${ }^{24}$ Por. DE nr 151; D. Salachas, I matrimoni misti..., s. 70; J. Syry JCZyK, Kanoniczne prawo karne. Część szczegółowa, Warszawa 2003, s. 40-47.
} 
religijnym, ale też podkreśla się ducha ekumenicznego, przez rezygnację z kar kościelnych. Jest to także konsekwencja zapisu, iż strona katolicka 'uczyni wszystko, co w jej mocy' w odniesieniu do składanego przyrzeczenia.

Przy zawieraniu małżeństwa katolika z osobą nieochrzczona (małżeństwo mieszane w sensie szerokim, tj. im podobne) zgodnie z kan. $1086 \$ 1^{25}$ należy wspomnieć o jeszcze innym warunku, który winien być wypełniony, aby otrzymać zezwolenie, mianowicie potrzebna jest dyspensa ${ }^{26}$ od przeszkody disparitas cultus, bo bez niej małżeństwo byłoby nieważne. $W \$ 2$ wymienionego kanonu zaznacza się, że dyspensy można udzielić po wypełnieniu warunków według kan. 1125 i 1126. Tak więc prawo zrównuje takie małżeństwo z mieszanym małżeństwem co do obowiązku składania odpowiednich oświadczeń i przyrzeczeń oraz pouczenia stron.

Małżeństwo strony katolickiej z osobą, która notorycznie porzuciła wiarę katolicką w Instrukcji z 1986 r., znajduje uwydatnione w postaci kilku przypadków. Są to: osoby, które formalnym aktem odstąpiły od Kościoła; osoby wprawdzie nie formalnie, ale praktycznie i publicznie odstąpiły od Kościoła, tak że faktu nie da się ukryć; osoby, które trwają notorycznie w karach kościelnych; osoby, które uważają się za niewierzących lub ateistów oraz osoby, które ostentacyjnie nie praktykują (nr 77). Wymagania w tym przypadku są większe, gdyż niebezpieczeństwo naruszenia prawa Bożego jest bardziej realne. Potrzebne jest więc również odpowiednie zezwolenie ordynariusza miejsca (kan. $1071 \$ 2$, punkt 4), wypełnienie warunków zgodnie z kan. 1125, przy zastosowaniu odpowiednich modyfikacji. Istotną modyfikację wprowadziła tutaj Konferencja Episkopatu Polski stanowiąc, że obie strony przyrzekają, że wszystkie dzieci zrodzone z tego małżeństwa będą ochrzczone i wychowane w duchu katolickim. Tak więc wymagania wobec strony, która notorycznie porzuciła wiarę

\footnotetext{
25 „Nieważne jest małżeństwo między dwiema osobami, z których jednak została ochrzczona w Kościele katolickim lub była do niego przyjęta, a druga jest nieochrzczona".

${ }^{26}$ Por. U. Nowicka, Przeszkoda różności religii..., s. 225-233.
} 
katolicką, są wyższe niż w przypadku małżeństw mieszanych w sensie ścisłym.

\section{Dyspensowanie od zachowania formy kanonicznej}

Małżeństwo jako przymierze i umowa domaga się niezbędnych formalności związanych z jego zawieraniem, w tym także małżeństwo mieszane. Ustawodawca o tym stanowi w kan. 1127. W $\$ 1$ tej normy zaznacza, że co do formy małżeństwa mieszanego należy zachować przepisy kan. 1108, czyli iż małżeństwo ma być zawierane wobec świadka kwalifikowanego i dwóch świadków zwykłych. Ta forma prawna jest wymagana do ważności aktu zgody. Rozwiązanie to jednak nie posiada charakteru bezwzględnego. Prawodawca bowiem we wspomnianym już kanonie nie wykluczył również ewentualności zawarcia ważnego związku małżeńskiego przez stronę katolicką ze stroną akatolicką należącą do obrządku wschodniego, z pominięciem formy kanonicznej. Co więcej w \$2 kan. 1127 stworzył on możliwość uzyskania dyspensy od konieczności zachowania formy kanonicznej. Jest rzeczą oczywistą, iż podjęcie tak ważkiej decyzji jaką jest dyspensa staje się możliwe jedynie w przypadku spełnienia pewnych warunków określonych w wymienionym kanonie. W nim zwraca się uwagę na kompetentną władzę do udzielenia dyspensy, na przyczyny jej udzielenia i na konieczność zachowania formy publicznej przy zawieraniu małżeństwa mieszanego ${ }^{27}$. Prawodawca w kan. $1127 \$ 2$ KPK stwierdził wyraźnie, że kompetentnym do udzielenia dyspensy jest ordynariusz miejsca strony katolickiej. W tym przypadku są to osoby wymienione w kan. $134 \$ 2$ w łączności z kan. 368 KPK. Należy jednak dopowiedzieć, iż ordynariusz miejsca dysponuje zwyczajną władzą dyspensowania od wymogów związanych z zachowaniem formy kanonicznej wyłącznie w dwóch przypadkach: 1) w niebezpieczeństwie śmierci (kan. 1079 \$1); i także 2) w odniesieniu do małżeństw mieszanych (kan. 1127 \$2).

\footnotetext{
${ }^{27}$ Por. G. DzIerżon, Dyspensowanie od formy zawarcia małżeństw mieszanych, Ius Matrimoniale 11(17)2006, s. 93.
} 
Co do przypadku niebezpieczeństwa śmierci to kan. $1079 \$ 1$ przyznaje ordynariuszowi miejsca władzę dyspensowania swoich podwładnych, gdziekolwiek przebywających oraz wszystkich pozostających na jego terytorium, od formy kanonicznej zawarcia małżeństwa. W tych samych okolicznościach władza dyspensowania od formy małżeńskiej przysługuje także proboszczowi, kapłanowi i diakonowi delegowanemu do asystowania przy zawieraniu małżeństwa oraz kapłanowi i diakonowi obecnemu podczas zawierania małżeństwa w formie nadzwyczajnej po myśli kan. $1116 \$ 1$ i $\$ 2$. Wymienione jednak tutaj - poza ordynariuszem miejsca - kategorie osób tylko wówczas posiadają władzę, o której mowa, gdy nie można się odnieść do miejscowego ordynariusza. Z kolei w drugim przypadku, $\mathrm{w}$ odniesieniu do małżeństw mieszanych ${ }^{28}$, kompetentnym podmiotem do udzielenia dyspensy od formy kanonicznej jest ordynariusz miejsca według kan. $1127 \$ 2$.

Wreszcie należy zauważyć, że analizowany kanon 1127 wymaga przed podjęciem stosowanej decyzji spełnienia jeszcze jednego warunku, tzn. konsultacji z ordynariuszem miejsca zawarcia małżeństwa. Ta konsultacja jest zasadna ${ }^{29}$, gdyż ordynariusz miejsca zawarcia małżeństwa zna lepiej uwarunkowania środowiskowe wskazujące na udzielenie dyspensy lub przemawiające przeciw wydaniu dyspensy. Słusznie też podkreśla Dzierżon odwołując się do kan. $127 \$ 2$ n. 2 KPK, że gdyby ordynariusz miejsca strony katolickiej nie skonsultowałby sprawy z ordynariuszem miejsca zawarcia małżeństwa, to wówczas wydana przez niego dyspensa byłaby nieważna ${ }^{30}$.

\footnotetext{
${ }^{28} \mathrm{Na}$ marginesie problematyki dyspensowania od formy kanonicznej wypada dopowiedzieć, że z odpowiedzi Papieskiej Komisji do Autentycznej Interpretacji KPK z 14 V 1985 roku wynika, że w zwyczajnych okolicznościach nie można dyspensować od formy kanonicznej zawarcia małżeństwa dwojga katolików. AAS 77 (1985) s. 771; por. W. Góralski, Dyspensowanie od formy zawarcia małżeństwa w świetle nowego Kodeksu Prawa Kanonicznego, Prawo Kanoniczne 31(1988) nr 1-2, s. 95-98.

${ }^{29}$ Por. F. Aznar Gil, Derecho Matrimonial Canónico, t. 3, Salamanca 2003, s. 100.

${ }^{30}$ Por. G. Dzierżon, Dyspensowanie od formy..., s. 93.
} 
Należy też nadmienić, że prawodawca stawia większe wymagania odnośnie do przyczyny dyspensowania. Nie wystarczy słuszna i racjonalna przyczyna zgodnie z kan. $90 \$ 1$, ale poważna trudnośćc ${ }^{11}$, której jednak nie należy łączyć z niemożliwością. Dyrektorium Ekumeniczne zalicza do przyczyn, które mogą być wzięte pod uwagę przy udzieleniu dyspensy jako znaczące: zachowanie harmonii rodzinnej, uzyskanie zgody rodziców na małżeństwo, uznanie szczególnego zaangażowania religijnego strony, względnie jej więź pokrewieństwa z szafarzem innego Kościoła lub Wspólnoty eklezjalnej ${ }^{32}$. Dalej stwierdzono, że naciski Kościołów lub Wspólnot eklezjalnych co do konieczności zachowania przez ich członków form zawarcia małżeństwa funkcjonujących w tych wspólnotach nie mogą stać się powodem automatycznego udzielenia dyspensy ${ }^{33}$. Natomiast Instrukcja z 1986 zawiera zapis, że mogą to być zwyczajne, obiektywne, tradycyjnie uwzględniane w nauce prawa kanonicznego, a nade wszystko takie, które sygnalizuje motu proprio De episcoporum muneribus, tzn. dobro duchowe wiernych (por. nr 85). Z kolei Instrukcja z $1987^{34}$ nie zawiera żadnej wzmianki w tym względzie. Natomiast stan niemożliwości moralnej zawarcia małżeństwa w formie kanonicznej stwierdza sam ordynariusz miejsca na podstawie relacji duszpasterza. Mogą bowiem zaistnieć sytuacje u jednej lub u drugiej strony takie opory

${ }^{31}$ Warto nadmienić o zapytaniu z r. 1972 skierowanym do Papieskiej Komisji do Spraw Interpretacji Dekretów Soboru Watykańskiego II o następującej treści: czy zgodnie z normami motu proprio Matrimonia mixta z dnia 31 marca 1970 ordynariusz miejsca mógłby udzielić dyspensy od formy kanonicznej małżeństwa mieszanego, jeśli jedna ze stron byłaby katolikiem, druga zaś zostałaby wprawdzie ochrzczona w Kościele katolickim, lecz następnie przystąpiła do wspólnoty akatolickiej. Odpowiedź była pozytywna, ale podkreślono, iż byłoby to możliwe w przypadku poważnych trudności (dummodo graves difficultates). AAS 64(1972), s. 397; por. także G. DzIERżon, Dyspensowanie od formy... s. 95.

${ }^{32} \mathrm{DE}$ nr 154.

${ }^{33}$ Tamże, nr 155.

${ }^{34}$ Konferencja Episkopatu Polski, Instrukcja Episkopatu Polski w sprawie duszpasterstwa małżeństw o różnej przynależności kościelnej (11.03.1987), (odtąd Instrukcja z 1987), w: Papieska Akademia Teologiczna, Małżeństwa mieszane, red. Z.J. Kijas, Kraków 2000, s. 133-143. 
w stosunku do formy kanonicznej, uwarunkowane bądź przesłankami obiektywnymi, bądź subiektywnymi, że strony zdecydowane będą zawrzeć związek niesakramentalny. W tym wypadku Kościół, udzielając dyspensy sankcjonuje niejako tę formę publiczną zawarcia małżeństwa, jaką strony wybiorą ${ }^{35}$.

W tym miejscu należy podkreślić wspomniany wymóg publicznej formy zawarcia małżeństwa przy dyspensie od formy kanonicznej. W analizowanym kan. $1127 \$ 2$ postanowiono, że wymóg ten posiada charakter unieważniający, czyli związek zawarty w formie niepublicznej byłby nieważny ${ }^{36}$. Prawodawca uznał zatem formę publiczną za istotny element ${ }^{37}$, a konferencje episkopatu mogą ustalić 'niekanoniczne' formy zawarcia małżeństwa. Zgodnie z nr 93 Instrukcji z 1986 takimi są: 1) przed ministrem niekatolickim; 2) w urzędzie stanu cywilnego; 3) w gronie rodzinnym w formie religijnej ${ }^{38}$, pod warunkiem obecności świadków, którzy będą mogli publicznie poświadczyć o fakcie zawarcia małżeństwa. Wyboru tego dokonują nupturienci wobec duszpasterza. Jeśli narzeczeni wybrali jedną z tych form zawarcia małżeństwa oraz została udzielona dyspensa, małżeństwo w ten sposób zawarte staje się ważne w obliczu Kościoła, a więc sakramentalne i nierozerwalne. Dlatego dezaprobuje się jakąkolwiek praktykę ponownego zawierania. Zabrania się stosować podwójną ceremonię, w której asystujący katolicki i niekatolicki szafarz, stosując równocześnie własny obrzęd, pytają o wyrażenie zgody stron ( $\$ 3$, kan. 1127). Warto pamiętać, że gdy ordynariusz miejsca zwalnia od zachowania formy kanonicznej, udziela się równocześnie dyspensy od obowiązku głoszenia zapowiedzi (nr 93 Instrukcji z 1986).

\footnotetext{
${ }^{35}$ Instrukcja z 1986, nr 91.

${ }^{36}$ Por. G. Dzierżon, Dyspensowanie od formy..., s. 99.

${ }^{37}$ Salachas komentując kan. 781, n. 2 KKKW stwierdził, iż wymaganie obligujące osoby należące do Kościołów i Wspólnot kościelnych protestanckich do zachowania formy publicznej zawarcia małżeństwa wypływa z prawa naturalnego. Por. D. SALACHas, Il Sacramento del matrimonio nel Nuovo Diritto Canonico delle Chiese orientali, Bologna 1994, s. 60.

${ }^{38}$ Wydaje się, że KEP w nowej Instrukcji zrezygnuje z tej 'niekanonicznej' formy zawarcia małżeństwa mieszanego.
} 
Odnośnie do formy zawierania małżeństwa katolika z osobą nieochrzczoną, czyli zachodzi przeszkoda disparitas cultus, także stosuje się przepisy o możliwości dyspensowania od formy kanonicznej, zgodnie z kan. 1129, po wypełnieniu także innych warunków, o których mowa w kan. 1125 i 1126 i uzyskaniu dyspensy od tej przeszkody zrywającej.

Co do formy zawierania małżeństw przez osoby, które zostały wymienione przez KEP jako podobne do małżeństw mieszanych, należy stwierdzić, że obowiązuje ich forma kanoniczna i nie ma możliwości dyspensowania od formy, gdyby te osoby zawierały małżeństwo z katolikiem. Są one wciąż katolikami, mimo niewiary, niepraktykowania, czy też wystąpienia formalnego z Kościoła. Nie ma racji i możliwości dyspensowania jak to wynika z odpowiedzi Papieskiej Komisji do Autentycznej Interpretacji KPK z 14 maja 1985 roku $^{39}$.

Gdy chodzi o formę celebracji liturgicznej małżeństwa mieszanego, to przy zachowaniu formy kanonicznej, na ogół odbywa się według rytuału rzymskiego i poza liturgią eucharystyczną. Jednakże dla słusznych powodów biskup diecezji może pozwolić na sprawowanie Eucharystii. W tym ostatnim przypadku decyzję o dopuszczeniu lub nie, niekatolickiej strony małżeństwa do Komunii św. winno się podjąć zgodnie z ogólnymi normami istniejącymi w tej dziedzinie, zarówno w odniesieniu do chrześcijan wschodnich, jak też do innych chrześcijan, uwzględniając przy tym tę szczególną sytuację zawierania sakramentu małżeństwa chrześcijańskiego przez dwie osoby ochrzczone (DE nr 159). Chociaż małżonkowie w małżeństwach mieszanych mają wspólne sakramenty chrztu i małżeństwa, udział w Eucharystii może być tu tylko wyjątkowy, a w związku z tym, powinno się w każdym przypadku zachować normy podane niżej, a dotyczące dopuszczania chrześcijanina niekatolika do komunii eucharystycznej, jak też normy dotyczące udziału katolika w komunii eucharystycznej w innym Kościele (tamże nr 160). Oznacza to, że wyznawcy innych Kościołów lub Wspólnot chrześcijańskich, które podzielają wspólną z Kościołem katolickim wiarę w Eucharystię, mogą także na

\footnotetext{
${ }^{39}$ AAS 77(1985), s. 771.
} 
wspomnianych wyżej warunkach przyjąć komunię świętą podczas zawierania małżeństwa ${ }^{40}$.

Zawarcie małżeństwa strony katolickiej z osobą nie ochrzczoną odbywa się poza Mszą świętą i według specjalnego obrzędu podanego w Obrzędach sakramentu małżeństwa nr 61-76 ${ }^{41}$. Wymienione dokumenty określają także możliwości i sposób czynnego udziału duchownych i osób świeckich przy sprawowaniu liturgii zawierania małżeństwa w Kościele katolickim lub innych Wspólnotach eklezjalnych.

\section{Asystencja kapłana, gdy jedna strona przynależy do wspólnoty wschodniej, w formie zwyczajnej i nadzwyczajnej ${ }^{42}$}

Wyróżnienie jako osobnego punktu w problematyce związanej z małżeństwami mieszanymi przez zaakcentowanie obecności prezbitera przy jego zawieraniu ma swoje uzasadnienie w związku ze zmianami, których dokonał papież Franciszek w celu zgodności między kodeksem łacińskim i KKKW w sprawach małżeńskich. Ponadto istnieje także potrzeba zaakcentowania podmiotów, które mogą dyspensować od formy kanonicznej w przypadku katolików wschodnich w formie zwyczajnej i nadzwyczajnej.

W KPK formę kanoniczną zwyczajną reguluje kan. 1108, który składał się z dwu paragrafów. Papież Franciszek poprzez motu proprio De concordia inter Codices [DCIC] $w$ art. $6^{43}$ wprowadził do

\footnotetext{
${ }^{40}$ Por. J. Krzywda, Ewolucja zasad i norm dotyczacych małżeństw mieszanych w świetle wymogów Kodeksu Prawa Kanonicznego Kościoła Katolickiego, w: Papieska Akademia Teologiczna, Małżeństwa mieszane, red. Z.J. Kijas, Kraków 2000, s. 92.

${ }^{41}$ Por. Obrzędy sakramentu matżeństwa dostosowane do zwyczajów diecezji polskich, Katowice 1974; Kongregacja NAUKi Wiary, Instrukcja o małżństwach mieszanych 'Matrimonii sacramentum, AAS 58(1966), nr V; Matrimonia Mixta, nr 11, s. 108.

${ }^{42}$ Ten punkt zasadniczo opiera się na publikacji wraz z literaturą tam zamieszczoną: H. STAWNIAK, Modyfikacje przepisów dotyczących formy zawarcia matżeństwa wprowadzone przez papieża Franciszka, w: Chrzest i małżeństwo - harmonizacja przepisów, red. H. Stawniak, R. Kamiński, Warszawa 2018, s. 94-104.

${ }^{43} „ \$ 3$. Solus sacerdos valide assistit matrimonio inter partes orienales vel inter partem latinam et partem orientalem sive catholicam sive non catholicam". DCIC art. 6 .
} 
wymienionego kanonu paragraf trzeci. Brzmi on następująco: „Tylko kapłan asystuje ważnie przy zawieraniu małżeństwa dwóch stron wschodnich lub małżeństwa zawieranego pomiędzy stroną katolicką łacińską i katolicką wschodnią lub niekatolicką wschodnią". W tym kontekście należy podkreślić, że wiadomo, iż KKKW do ważności małżeństwa domaga się przyjęcia zgody przez asystującego i ritus sacer kapłana. Kan. $828 \$ 1$ stanowi: „Tylko te małżeństwa są ważne, które są zawierane z zachowaniem świętego obrzędu [rito sacro] wobec Hierarchy miejsca lub proboszcza miejsca lub kapłana, który od jednego z nich otrzymał upoważnienie do błogosławienia małżeństwa i wobec przynajmniej dwóch świadków, jednak według kanonów, które następują, z uwzględnieniem wyjątków, o których mowa w kan. 832 i $834 \$ 2 ”$. Natomiast w $\$ 2$ wyjaśnia się, że za święty uważany jest obrzęd z udziałem kapłana asystującego i błogosławiącego. Interpretując ten kanon kanoniści podkreślają, że uprawnionymi do błogosławieństwa małżeństwa są jedynie prezbiterzy oraz biskupi. Co więcej, Joseph Prader stwierdził, iż ze źródeł kanonicznych wynika, że w żadnym z Kościołów wschodnich małżeństwo nie było błogosławione przez diakona ${ }^{44}$. Potwierdza to także Katechizm Kościoła Katolickiego w art. 1623.

Konsekwentnie diakoni wschodni nie mogą błogosławić i nie mogą ważnie asystować przy zwyczajnej formie zawarcia małżeństwa. Przeciwnie, soborowa Konstytucja Lumen gentium w art. 29 i kan. $1108 \$ 1$ KPK. Dokumenty te pozwalały na asystowanie przy zawarciu małżeństwa diakonowi. Stąd były wieloletnie dyskusje o to, czy diakon łacinnik może ważnie asystować i błogosławić małżeństwo, kiedy przynajmniej jedna ze stron przynależy do wspólnoty wschodniej katolickiej lub niekatolickiej? ${ }^{45}$.

\footnotetext{
${ }^{44}$ Por. J. Prader, Matrimonio in Oriente e in Occidente, Roma 2003, s. 226.

${ }^{45}$ Prader uważał, że były ważne, [Tamże, s. 266.], natomiast inni jak np. Salachas i Nitkiewicz uważali przeciwnie, tj. ,że były nieważne, [por. D. SALACHAs, K. NitKIEWICZ, Inter Eclesial Relations between Esternand Latin Catholices, Washington 2009, s. 29; także P. Gefaell, Commenti al m.p. De Concordia inter Codices, Ius Ecclesiae 21,1 (2017), s. 166.
} 
W wyjaśnieniu tych różnic zdań trzeba dopowiedzieć, że tradycja Kościoła łacińskiego uznawała znak sakramentalny w konstytutywnej zgodzie małżeńskiej stron między ochrzczonymi. Duchowny był świadkiem kwalifikowanym tego wydarzenia stąd ordynariusz miejsca i proboszcz mogli delegować diakona, a nawet po wypełnieniu warunków kan. 1112 KPK, także osobę świecką. Oczywiście delegacja diakona lub świeckiego nie była uczestnictwem ani we władzy święceń ani jurysdykcyjnej. Odmiennie tę sprawę traktowała tradycja Kościołów wschodnich. Wiąże się ona $\mathrm{z}$ instytucją rytu świętego od VIII wieku, a już od XII wieku ukształtowała się doktryna, zgodnie z którą istota sakramentu małżeństwa wyraża się w błogosławieństwie kapłańskim. Kapłan jest więc szafarzem sakramentu małżeństwa ${ }^{46}$. Zatem w porządku wschodnim udział kapłana nie wyczerpuje się na przyjęciu zgody małżeńskiej, ale też dotyczy udzielenia błogosławieństwa. Błogosławienie małżeństwa oznacza wypełnienie funkcji rzeczywistego szafarza sakramentu i ta władza uświęcenia sakramentalnego jest zakotwiczona w święceniach. Luigi Sabbarese nadmienia, że zawieranie sakramentu ma własną epiklezę, czyli wypraszanie przez kapłana Ducha Świętego na małżonków ochrzczonych, aby byli złączeni przez Boga na obraz Chrystusa z Kościołem i by byli konsekrowani dzięki łasce sakramentalnej. Podobnie jak podczas Mszy Świętej tylko kapłan może wypowiadać epiklezę nad chlebem i winem, tak tylko kapłan może ją wypowiadać przy błogosławieniu małżeństwa według tradycji wschodniej, bo ta władza jest związana ze święceniami prezbiteratu ${ }^{47}$. Z kolei, Grzegorz Kadzioch wykazał, że od czasów wczesnochrześcijańskich małżeństwa były zawierane

\footnotetext{
${ }^{46}$ Por. J. Prader, La forma del celebrazione del matrimonio, w: Il matrimonio nel Codice dei Canoni delle Chiese Orientali, Citta del Vaticano 1994, s. 286; G. DzIERżon, Zmiany zapisów kanonów w obszarze materialnego prawa matżeńskiego na mocy motu proprio „De Concordia inter Codices”, Ius Matrimoniale 28(2017), nr 2, s. 8-7.

${ }^{47}$ Por. L. Sabbarese, Commento alle modifiche apportate al Codice con il m.p. «De Concordia inter Codices», Ephemerides Iuris Canonici 57 (2017), s. 616.
} 
w czasie Eucharystii, stąd udział kapłana był konieczny ${ }^{48}$. Według tego ostatniego autora, ryt święty nie jest obrzędem pozostającym w relacji zewnętrznej do formy kanonicznej, ale jest elementem istotnym sakramentalności, wynikającym z woli Kościoła. Trzeba wyartykułować to, że tak dzieje się z woli Kościoła, zatem na podstawie prawa kościelnego, iż ritus sacer wpisuje się jako element ważności małżeństwa, w którym forma kanoniczna pozostaje w ścisłym związku z przepisami o formie liturgicznej. W Kościołach wschodnich, forma liturgiczna i forma prawna w małżeństwie stanowią jedność, są wewnętrznie złączone.

W kontekście nowego $\$ 3$ kan. 1108 można pytać o ważność małżeństw zawartych wobec diakona przed motu proprio papieża Franciszka? W tym przypadku, w odpowiedzi na to pytanie, zwraca się uwagę na kan. 14 KPK oraz kan. $1496 \mathrm{KKKW}$, w których stwierdza się, że w wątpliwości prawnej, ustawy nie obowiązują, nawet unieważniające i uniezdalniające, zatem te małżeństwa należy uważać za ważnie zawarte ${ }^{49}$.

W podsumowaniu komentarza do art. 6 DCIC należy stwierdzić, że brak zgodności między kanonistami w kwestii szafarstwa sakramentu małżeństwa zawieranego pomiędzy dwiema stronami wschodnimi lub między stroną łacińską i stroną wschodnią czy to katolicką, czy to akatolicką powodował, że prawodawca zdecydował się na zapis w kodeksie łacińskim, że tylko kapłan może asystować. Pablo Gefaell jest zdania, i chyba słusznie, że art. 6 DCIC byłby jeszcze klarowniejszy, gdyby wprost potwierdzono, że asystencja/interwencja kapłana zawiera w sobie koniecznie błogosławieństwo małżonków, tymczasem tekst promulgowany można zrozumieć, że wystarczy sama 'asystencja' formalna, bez błogosławieństwa liturgicznego ${ }^{50}$.

\footnotetext{
${ }^{48}$ Por. G. Kadzioch, Il ministro del sacramento del matrimonio nella tradizione e nel diritto canonico latino e oriente, Roma 1997, s. 222.

${ }^{49}$ Por. Commento al Codice dei canoni..., s. 1170; P. Gafaell, Commenti al m. p. De Concordia ..., s. 166.

${ }^{50}$ Por. P. Gafaell, Commenti al m. p. De Concordia..., s. 166.
} 
Z uwagi na wprowadzenie do kan. 1108 paragrafu 3 staje się konieczna modyfikacja kan. $1127 \$ 1 \mathrm{KPK}$. Według tego kanonu w wersji z 1983 roku, w przypadku małżeństwa mieszanego między katolikiem i stroną niekatolicką obrządku wschodniego, kanoniczna forma zawarcia wymagana była tylko do godziwości, do ważności zaś konieczny był udział świętego szafarza [interventus ministra sacri]. Nowa wersja kanonu, poprzez art. 11 DCIC $^{51}$, domaga się w tej sytuacji udziału kapłana [interventus sacerdotis] ${ }^{52}$. Zatem jeśli jest zawierane małżeństwo mieszane między katolikiem - łacinnikiem lub wschodnim - i niekatolikiem, do ważności celebracji jest konieczny udział kapłana katolickiego lub niekatolickiego. Czyli w tym przypadku nie można delegować diakona ani świeckiego ze względów praktycznych i ekumenicznych ${ }^{53}$. Z kolei w małżeństwie katolika - łacinnika lub wschodniego - i protestanta lub nieochrzczonego, do ważności jest wymagana forma kanoniczna po myśli kann. 828 KKKW i 1108 KPK.

Na jeszcze jeden ważny szczegół należy zwrócić uwagę, mianowicie na kwestię władzy dyspensowania od formy przy małżeństwach mieszanych. Otóż Ordynariusz miejsca łacinnik może dyspensować od formy kanonicznej na mocy kan. $1127 \$ 2$ w przypadku zawierania małżeństwa między katolikiem łacińskim i protestantem lub między katolikiem łacinnikiem i nieochrzczoną osobą. Natomiast w przypadku katolików wschodnich, ta dyspensa, według kan. $835 \mathrm{KKKW}^{54}$, jest zarezerwowana Stolicy Apostolskiej lub Patryjarsze. Ten ostatni może dyspensować tylko dla najpoważniejszej przyczyny. Zatem

\footnotetext{
51 „Ad formam quod attinet in matrimonio mixto adhibendam, servatur praescripta can. 1108; si tamen pars matrimonium contrahit cum parte non catholica ritus corientalis, forma canonica celebrationis servanda est ad liceitatem tantum; ad validitatem autem requiritur interventus sacerdotis, servatis aliis de iure servandis". Art. 11 DCIC.

${ }^{52}$ Por. J. Abbass, De Concordia..., s. 342-343; P. Gefaell, Commento al m. p. De Concordia ..., s. 167; G. DzIerżon, Zmiany zapisów..., s. 6-7.

${ }^{53}$ Por. P. Sza bó, Forma canonica..., s. 256-258.

${ }^{54}$ „Dispensatio a forma celebrationis matrimonii iure praescripta reservatur Sedi Apostolicae vel Patriarchae, qui eam ne concedat nisi gravissima de causa”. CCEO can. 835. Por. też Komentarz, s. 852.
} 
ordynariusz miejsca łacinnik nie mógłby dyspensować od formy kanonicznej w przypadku małżeństwa między katolikiem wschodnim, jemu poddanym, ze stroną protestancką lub nieochrzczoną ${ }^{55}$.

W dalszym ciągu pozostaje jednak różnica między nową wersją kan. $1127 \$ 2$ i odpowiadającym mu kan. $834 \$ 2 \mathrm{KKKW}^{56}$, w którym to kanonie wschodnim interwencję kapłana dookreśla się jako błogosławieństwo kapłana, zaś w łacińskim nie. Jednak nie ma dzisiaj wątpliwości, że owa interwencja musi być interpretowana w sensie kan. $781 \$ 2 \mathrm{KKKW}$ i w myśl art. $4 \$ 1,2^{\circ}$ instrukcji Dignitas connubii jako ritus sacer, czyli z błogosławieństwem kapłańskim ${ }^{57}$. Ginter Dzierżon fakt, iż ustawodawca w legislacji łacińskiej nie posłużył się terminem 'benedictio' funkcjonującym w legislacji wschodniej, tłumaczy tym, żeby nie zatrzeć różnic doktrynalnych występujących pomiędzy tradycją łacińską oraz tradycją wschodnią ${ }^{58}$.

W podsumowaniu interpretacji zmian co do formy zwyczajnej zawarcia małżeństwa, które zaszły poprzez art. 11 DCIC w kanonie $1127 \$ 1$ należy stwierdzić, że ta modyfikacja kończy spór doktrynalny dotyczący podmiotu uprawnionego do błogosławieństwa w przypadku małżeństw mieszanych. W ten sposób, od strony praktycznej, unika się także nieważności zawieranych małżeństw mieszanych oraz wprowadza się ekumeniczne postulaty soborowe ${ }^{59} \mathrm{~W}$ tej materii.

Z kolei zawieranie małżeństwa w formie nadzwyczajnej jest unormowane w kodeksie Jana Pawła II w kan. 1116. W pierwszym paragrafie stanowi się, iż jeśli świadek urzędowy kompetentny do asystowania przy małżeństwie jest nieosiągalny, ponieważ nie ma możliwości ani

\footnotetext{
${ }^{55}$ Por. L. Sabbarese, Commento alle modifiche..., s. 620; Studium Romanae Rotae, Corpus Iuris Canonici, II, Commento al Codice dei Canoni delle Chiese Orientali, a cura gi P.V. Pinto, Libreria Editrice Vaticana 2001, s. 716.

${ }^{56}$ Por. Commento al Codice dei Canoni..., s. 715.

${ }^{57}$ Por. J. Hendriks, Giurisdizione ecclesiastica e validitá del matrimonio dei non cattolici, w: AA.VV., „Iustitia et iudicium”. Studi di diritto matrimoniale e processuale canonico in onore di Antoni Stankiewicz, a cura di J. Kowal, J. Llobell, vol. III, LEV, Cittá del Vaticana 2010, s. 1614-1615.

${ }^{58}$ Por. G. Dzierżon, Zmiany zapisów..., s. 7-8.

${ }^{59}$ Por. DE nr 18.
} 
udania się do niego, bez poważnej niedogodności, ani udania się do pobłogosławienia małżeństwa, a nupturient pragnie tego sakramentu, może go ważnie i godziwie zawrzeć wobec samych zwykłych świadków w dwóch okolicznościach: 1. niebezpieczeństwie śmierci oraz 2. poza niebezpieczeństwem jedynie wtedy, jeśli roztropnie przewiduje się, iż okoliczności będą trwały przez miesiąc. W paragrafie 2 kan. 1116 zawarto myśl, że wyraźnym życzeniem prawodawcy jest, aby w obydwu okolicznościach, jeśli jest osiągalny kapłan lub diakon (bez władzy asystowania), był on poproszony i obecny wraz ze świadkami zwykłymi przy zawieraniu małżeństwa, z zachowaniem przepisu, że małżeństwo wobec samych świadków byłoby ważne ${ }^{60}$.

W związku z kan. $833 \mathrm{KKKW}^{61}$, który zawiera jeszcze inne treści w ramach ujednolicenia i harmonii między kodeksami motu proprio DCIC dodaje $\$ 3$ do kan. 1116 KPK stanowiąc poprzez art. 10, iż ordynariusz miejsca może udzielić jakiemukolwiek kapłanowi katolickiemu władzy błogosławienia małżeństwa wiernych Kościołów wschodnich niepozostających w pełnej wspólnocie z Kościołem łacińskim, którzy dobrowolnie o to proszą, jeśli nic nie stoi na przeszkodzie ważności i godziwości zawieranego związku małżeńskiego. Tenże kapłan, zachowując zawsze konieczną roztropność, winien poinformować o tym właściwą władzę zainteresowanego Kościoła niekatolickiego ${ }^{62}$.

${ }^{60}$ Por. M. A. Żurowski, Kanoniczne prawo małżeńskie Kościoła katolickiego, Katowice 1987, s. 320-324; P. M. GAJDA, Prawo małżeńskie Kościoła katolickiego, Biblos, Tarnów 2002, s. 193-195.

${ }^{61}$ Can. $833 \$ 1$. Hierarcha loci cuilibet sacerdoti catholico facultatem conferre potest matrimonium christifidelium alicuius Ecclesiae orientalia acatholicae, qui sacerdotem propriae Ecclesiae sine gravi incommodo adire non possunt, benedicendi, si sua sponte id petunt et dummodo nihil validae vel licitae celebrationi matrimonii obstet.

$\$ 2$. Sacerdos catholicus, si fieri potest, antequam matrimonium benedicit, auctoritatem competentem illorum christifidelium de hac re certiorem faciat.

${ }^{62}$ Art. 10 DCIC: $\$ 3$. In iisdem rerum adiunctis, de quibus in $\$ 1, \mathrm{nn} .1$ et 2 , Ordinarius loci cuilibet sacerdotl catholico facultatem conffere potest matrimonium benedicendi christifidelium Ecclesiarum orientalium quae plenam cum Ecclesia catholica communionem non habeant si sponte id petens, et dummodo nihil validae vel licitae celebrationi matrimonii obstet. Idem sacerdos, semper neccesaria cum 
Komentując kan. $833 \$ 1$ KKKW i nowy $\$ 3$ kan. 1116 [art. 10 DCIC] Pablo Gefaell zauważa jednak pewną różnicę między tymi sformułowaniami. W Kodeksie wschodnim jako warunek udzielenia upoważnienia do błogosławienia przez kapłana katolickiego dwoje ortodoksów jest okoliczność „niemożliwości udania się do kapłana własnego bez poważnej niedogodności”, natomiast tego nie ma w art. 10 DCIC. Gefaell jest zdania, że warunek ten jest wpisany implicite w nowy $\$ 3$ kan. 1116, gdyż unormowanie to wychodzi naprzeciw sytuacjom, gdy brak jest własnego kapłana i związek małżeński jest zawierany w formie nadzwyczajnej. Ponadto pomijanie tego warunku, niemożliwości udania się do kapłana własnego bez poważnej niedogodności, otworzyłoby serię kontrowersji ekumenicznych z władzą Kościołów niekatolickich ${ }^{63}$. Nie jest to słuszne spostrzeżenie, gdyż tekst art. 10 DCIC mówi o wszystkich okolicznościach, które trzeba wziąć pod uwagę w tym także okoliczności gdy kapłan jest nieosiągalny lub nie można się do niego udać bez poważnej niedogodności.

W duchu ekumenicznym komentując, i to należy podkreślić, kapłan katolicki nie otrzymuje uprawnienia celebracji/asystowania małżeństwa wiernych niekatolików wschodnich, lecz tylko uprawnienie do błogosławienia małżeństwa zawieranego w formie nadzwyczajnej. Z tego też wynika, że Kościoły akatolickie też uznają ważność i godziwość małżeństw zawieranych wobec samych tylko świadków, gdyż nieracjonalne byłoby proszenie kapłana katolickiego o błogosławieństwo nieważnego związku. Ta benedykcja nic nie dodaje do godności sakramentalnej w przypadku zawierania małżeństw w formie nadzwyczajnej, bowiem także Kościoły niekatolickie wschodnie uznają ważność naturalną małżeństw celebrowanych bez ritus sacer,

prudentia, auctoritatem competentem Ecclesiae non catholicae, cuius interest, de re cerciorem faciat.

${ }^{63}$ Por. P. Gefaell, Commenti al m.p. De Concordia...., s. 172-173. 
gdy zachodzi okoliczność niemożliwości zwrócenia się do kapłana własnego ${ }^{64}$.

Lugi Sabbarese interpretując art. 10 DCIC w kontekście udzielania błogosławieństwa przez kapłana katolickiego przy zawieraniu takich małżeństw, zastanawia się czy konieczne jest uprawnienie błogosławienia, skoro jest ono odmienne od formy kanonicznej? Podziela on w tym względzie zdanie Gafaella, że jednak tak, gdyż w mentalności wschodniej błogosławieństwo kapłana jest pojmowane jako istotna część celebracji małżeństwa, stąd takie uregulowanie ${ }^{65}$. Odmienna jest jednak doktryna Kościoła katolickiego co do łączności naturalnego małżeństwa i sakramentalności zawieranego w formie nadzwyczajnej, gdyż jest ono ważne i godziwe od początku.

Kolejnym warunkiem do możliwości otrzymana uprawnienia błogosławienia niekatolików wschodnich $\mathrm{w}$ formie nadzwyczajnej jest to, że ci wierni spontanicznie proszą o pobłogosławienie ich małżeństwa. Zatem nie może być żadnej sugestii lub presji ze strony kapłana katolickiego, musi bowiem być uszanowane ius connubii, które to prawo postuluje wolność i możliwość decydowania co do możliwości celebrowania zawarcia małżeństwa. To spontaniczne proszenie ze strony akatolików jest w pewnym związku z kan. $844 \$ 3$ KPK zgodnie z którym: „Szafarze katoliccy godziwie udzielają sakramentu pokuty, Eucharystii i namaszczenia chorych członkom Kościołów wschodnich niemających pełnej wspólnoty z Kościołem katolickim, gdy sami o nie poproszą i są odpowiednio przygotowani [...]”. Kanoniści podkreślają,

\footnotetext{
${ }^{64}$ Por. P. Szabó, Matrimoni misti ed ecumenismo. Prospettive del riconoscimento ortodosso dei matrimonii misti con specjale riguardo al caso della celebrazione cattolica, Ius Ecclesiarum vehiculum caritatis, s. 235-259; L. SABbarese, Commento alle modifiche..., s. 627-628; J. AвBAss, De Concordia..., s. 340-341.

${ }^{65}$ Por. L. Sabbarese, Commento alle modifiche..., s. 628; P. Gefaell, L'armonizzazione tra i due Codici: problematiche giuridiche aperte, w: Pontificio Consiglio per i Testi Legislativi, L'attenzione pastorale per i fedeli orientali. Profili canonistici e sviluppi legislativi. Atti della giornata di studio tenutasi nel XXV anniversario della promulgazione del Codice dei Canoni delle Chiese Orientali, Roma, Sala San Pio X, 3 ottobre 2015, Libreria Editrice Vaticana Città del Vaticano 2017, s. 89.
} 
że takie rozwiązania prawne wynikają z soborowego Dekretu o ekumenizmie nr 14 i Dyrektorium ekumenicznego nr $122^{66}$. Natomiast Joseph Prader uważał, że już na podstawie kan. $844 \$ 3$ KPK można było błogosławić małżeństwa niekatolików wschodnich, gdy była konieczność zaradzenia ich prośbie ${ }^{67}$.

Również warunkiem do możliwości otrzymania uprawnienia błogosławienia niekatolików wschodnich jest fakt, że nic nie będzie przeszkadzać ważnemu lub godziwemu zawarciu małżeństwa. Jest to poważny obowiązek kapłana, gdyż trudno założyć, że akatolicy prosząc o posługę znają warunki ważności i godziwości zawarcia małżeństwa. Także trzeba zwrócić uwagę, czy deklaracja co do stanu wolnego jest wystarczająca. Należy przy tym pamiętać, że przy zawieraniu takich małżeństw zgodnie z kan. $781 \mathrm{KKKW}$ i art. $4 \$ 1,1^{\circ}$ Dignitas connubii trzeba uwzględniać ich prawo własne, które określa warunki ważności i godziwości zawieranego małżeństwa. Ponadto jak hipotetycznie zakłada Catozzella może się zdarzyć, że Kościół niekatolicki wschodni nie uznaje jako ważne małżeństwa błogosławione przez kapłana, który nie przynależy do tego Kościoła. W tej sytuacji kapłan katolicki nie powinien błogosławić małżeństwa, gdyby miało być nieważne w systemie prawnym tego Kościoła. Takie stanowisko potwierdza Vademecum Konferencji Biskupów Włoskich nr $43^{68}$.

Odmienne zdanie w tej sprawie ma Salachas, który twierdzi, że zgodnie z kan. $833 \$ 1$ KKKW i odpowiadającym mu $\$ 3$ kan. 1116 KPK, kapłan katolicki w tych okolicznościach nie musi zwracać uwagi na warunki ważności i godziwości w doktrynie i dyscyplinie Kościołów niekatolickich wschodnich ${ }^{69}$. Wydaje się, że kluczem do rozwiania tego dylematu jest okoliczność zawierania małżeństwa w formie nadzwyczajnej, czyli należy racje przyznać Salachasowi.

\footnotetext{
${ }^{66}$ Por. G. Dzierżon, Zmiany zapisów..., s. 13.

${ }^{67}$ Por. J. PRADER, La legislazione matrimoniale latina e orientale, s. 74.

${ }^{68}$ Por. F. Catozzolla, Le modifiche in materia di forma canonica del matrimonio introdotte dal Motu Proprio De Concordia inter Codices, Stato, Chiesa e pluralismo confessionale [Revista telematica (www.statoechiese.it), nr 6/2017, 20 febbraio 2017], s. 32-33.

${ }^{69}$ Por. D. Salachas, Il Sacramento del matrimonio..., s. 221.
} 
Wreszcie, obok warunków już wymienionych, kapłan katolicki, zachowując zawsze konieczną roztropność, powinien poinformować o tym fakcie właściwą władzę zainteresowanego Kościoła niekatolickiego. W \$2 kan. 833 KKKW natomiast mówi się, że kapłan katolicki zanim pobłogosławi, powinien powiadomić kompetentną władzę tych chrześcijan, gdy to jest możliwe. Czyli są różne sformułowania. Z tego wynika, że w świetle unormowań łacińskich można nie tylko przed, ale i po zawarciu małżeństwa poinformować odpowiednią władzę Kościoła niekatolickiego. Słusznie konstatuje Catozzella, że wymagana roztropność, może w niektórych przypadkach sugerować nie kontaktować się z tą władzą, ze względu na ewentualne poważne konsekwencje dla chrześcijan niekatolików, gdy kapłan jest moralnie pewny co do ważności tego małżeństwa ${ }^{70}$.

Uprawnienie błogosławienia małżeństwa niekatolików wschodnich w formie nadzwyczajnej może ordynariusz miejsca dać jakiemukolwiek kapłanowi katolickiemu. Zatem nie musi on posiadać władzy do asystowania do małżeństwa czy z urzędu, czy z delegacji, natomiast nie można tego uprawnienia przekazać diakonowi, ani tym bardziej osobie świeckiej.

Facultas matrimonium benedicendi w kontekście formy nadzwyczajnej przy małżeństwie akatolików wschodnich jest więc problematyką dość złożoną i rodzi także inne pytania ${ }^{71}$.

\section{Dyskusje wokół waloru prawnego formy kanonicznej i jej funkcji w kontekście aktu formalnego wystąpienia z Kościoła}

Już we wprowadzeniu artykułu został zasygnalizowany problem, który sprowadza się w swojej istocie do kwestii, czy forma kanoniczna w niektórych przypadkach, (nie tylko w małżeństwach mieszanych katolika ze stroną katolicką obrządku wschodniego), nie mogłaby być

\footnotetext{
${ }^{70}$ Por. F. Catozzella, Le modifiche..., s. 34.

${ }^{71} \mathrm{Na}$ przykład współczesne zapytania do papieskich Komisji, do Trybunału Sygnatury Apostolskiej. Por. G. Montini, La procedura di investigazione prematrimoniale é idonea alla comprovazione dello stato libero di fedeli ortodoxi che hanno il matrimonio civile, Periodica XCVII (2008), s. 244-255.
} 
ad liceitatem a nie ad validitatem? Na gruncie polskim ten problem był przedmiotem uwagi Piotra Majera ${ }^{72}$ i Rafała Wierzchanowskiego ${ }^{73}$, którzy odnieśli się do sugestii i propozycji autorów hiszpańskich i włoskich.

Najpierw należy zauważyć i to już wcześniej było wyartykułowane, że forma kanoniczna zawarcia małżeństwa odgrywa istotną rolę w kościelnym porządku prawnym, bowiem jawi się jako kryterium weryfikujące zaistnienie małżeństwa, stoi na straży pewności prawa, wymiaru sakramentalnego, krótko mówiąc, forma kanoniczna zabezpiecza wykonywanie jurysdykcji Kościoła nad małżeństwem ${ }^{74}$. „Ostateczną racją formy kanonicznej - tak konstatuje Majer - jest więc wymóg poznawalności sakramentalnego znaku małżeństwa. To pozwala na zachowanie i obronę innych znaczących walorów małżeństwa wobec sekularyzacji tej instytucji. Jednym z przejawów takiej sekularyzacji jest pozbawienie małżeństwa wymiaru publiczno-prawnego i spychanie go w stronę rzeczywistości prywatnej, traktując je jako sprawę sumienia, przy jednoczesnym propagowaniu praktycznego i prawnego zrównania małżeństwa $\mathrm{z}$ wolnymi związkami. Kanoniczna forma małżeństwa ma zatem znaczenie apostolskie i tym różni się od formy cywilnej”75.

We współczesnej doktrynie można spotkać stanowisko opowiadające się za zmianą waloru prawnego formy kanonicznej. Niektórzy kanoniści proponują, aby do ważności małżeństwa forma kanoniczna obowiązywała jedynie tych katolików, którzy zachowują komunię z Kościołem i nigdy nie odstąpili od niego formalnym aktem. Ci natomiast, którzy dokonali formalnej apostazji, byliby zobowiązani do zachowania formy kanonicznej tylko do godziwości, ad liceitatem.

\footnotetext{
${ }^{72}$ Por Tenże, Znaczenie kanoniczne formy..., s. 135-155.

${ }^{73}$ Por. Tenże, Czy jeszcze katolik?...., s. 292-301.

${ }^{74}$ Por. E. Górecki, Jurysdykcja Kościoła katolickiego nad małżeństwem kanonicznym, w: Skutki cywilnoprawne małżeństwa kanonicznego ze szczególnym uwzględnieniem prawa w Polsce, Słowacji i Republice Czeskiej, red. P. Ryguła, Kraków 2014, s. 35-44.

${ }^{75}$ P. MAJER, Znaczenie kanonicznej formy..., s. 150; por. też R. WiERzCHANOWski, Czy jeszcze katolik?...., s. 292-294.
} 
W ten sposób mogliby zawrzeć ważne małżeństwo, które byłoby uznane także we wspólnocie Kościoła ${ }^{76}$. Według opinii Miguel Angel Ortiza wymaganie zachowania formy kanonicznej od osób, które formalnym aktem wystąpiły z Kościoła narusza ich ius connubii, ponieważ nie mogą zawrzeć ważnego kontraktu. Według koncepcji wymienionego Autora, ius connubii mogłoby być realizowane w odwołaniu się do jakiejkolwiek publicznej formy. Wierni, którzy nie zachowaliby przewidzianej przez prawo formy, zawieraliby prawdziwe małżeństwo, lecz równocześnie, ze względu na brak wspólnoty znajdowaliby się w sytuacji nieprawidłowej. Taki stan wykluczałby ich z przyjmowania innych sakramentów ${ }^{77}$. Chociaż powyższa koncepcja przewiduje formę kanoniczną ad liceitatem, to jednak strony po zawarciu małżeństwa w innej publicznej formie, byłyby zobowiązane do stawienia się przed kompetentną władzą kościelną celem weryfikacji, czy ich małżeństwo spełnia wymogi z zakresy zdolności prawnej nupturientów i może być uznane za ważne, a więc również odnotowanie w księgach kościelnych. Adnotacja w rejestrach parafialnych byłaby więc specyficzną formą uznania węzła małżeńskiego. Forma kanoniczna obowiązująca jedynie ad liceitatem nie wiązałaby się z kanonizacją formy cywilnej, a to dlatego, iż normy nadal wymagałyby zachowania formy ze względu na materię sakramentalną. Stąd forma kanoniczna obowiązywałaby jak dotąd, lecz nie ad validitatem ${ }^{78}$.

Za pozytywny walor proponowanego rozwiązania Ortiza należy uznać afirmację ius connubii, troskę o pewność prawa oraz podkreślenie faktu, że zawarcie małżeństwa w innej formie, także cywilnej, nie musi wiązać się z negacją katolickiej koncepcji tej instytucji. Taki projekt rodzi jednak poważne obiekcje - tak zauważają Majer

\footnotetext{
${ }^{76}$ Por. M. A. ORTIz, L'obbligatorietà della forma canonica matrimoniale dopo il m.p. „Omnium in mentem”, Ius Ecclesiae 22(2010), s. 486-492; P. MonetA, I soggetti tenuti ad osservare la forma canonica: il canone 1117 CIC, w: La giurisdizione della Chiesa sul matrimonio e sulla famiglia, red. J. Carreras, Milano 1998, s. 177.

${ }^{77}$ Por. M. A. Ortiz, L'obbligatorietá..., s. 488; R. Wierzchanowski, Czy jeszcze katolik?...., s. 295.

${ }^{78}$ Por. M. A. Ortiz, L'obbligatorietá..., s. 490; R. Wierzchanowski, Czy jeszcze katolik?...., s. 295-296.
} 
i Wierzchanowski oraz Mingrandi ${ }^{79}$ - jak bowiem należałoby traktować małżeństwa tych, którzy nie zgłosili się do duszpasterza po zawartym małżeństwie? Majer przypuszcza, że przeważająca większość osób zawierających małżeństwo poza Kościołem nie byłaby wcale zainteresowana kanoniczną weryfikacją swego związku ${ }^{80}$. Zdaniem wymienionych kanonistów zniesienie obowiązku zachowania formy kanonicznej ad validitatem matrimonii nie znajduje wystarczającego uzasadnienia, gdyż wprowadziłoby to więcej zamieszania i wątpliwości niż potencjalnych korzyści.

W tym kontekście ciekawy i słuszny - jak się wydaje - jest postulat ${ }^{81}$ de lege ferenda Rafała Wierzchanowskiego, który optuje - przy małżeństwie apostaty - za możliwością dyspensy od formy kanonicznej z zastrzeżeniem, iż do ważności aktu wymaga się zachowania jakiejś formy publicznej (cywilnej lub religijnej). Oczywiście można w tym miejscu zapytać, czy osoby występujące z Kościoła będą zainteresowane ubieganiem się o dyspensę? Należy pamiętać, iż osoby występujące z Kościoła zawierają małżeństwo nie tylko między sobą, ale również z katolikami zachowującymi wszystkie więzy jedności i pragną by jego małżeństwo otrzymało pełną legitymizację ze strony wspólnoty Kościoła. Ponadto skoro prawodawca kościelny kierując się zasadą semel catholicus, semper catholicus postanowił związać występujących z Kościoła formalnym aktem ustawami czysto kościelnymi, to udzielając im dyspensy od formy w żaden sposób nie niweczy tego zamiaru. Dyspensa nie jest abrogacją normy prawnej, lecz rozluźnieniem prawa czysto kościelnego ze względu na szczególne okoliczności, jest też wyrazem dialogu, jaki może być prowadzony między prawodawcą a adresatami ustanowionych norm ${ }^{82}$. Można też dopowiedzieć, że poprzez możliwość zawarcia małżeństwa za

\footnotetext{
${ }^{79}$ Por. M. Mingrandi, Il motu proprio "Omnium in mentem” e il matrimonio canonico. Significo di una innovazione, Quaderni di Diritto Ecclesiale, brak, s. 176.

${ }^{80}$ P. MAJER, Znaczenie kanonicznej formy..., s. 150.

${ }^{81}$ Takie propozycje wysuwali uprzednio Salachas i Fornes.

${ }^{82}$ Por. R. Sobański, Recepcja normy kanonicznej, Śląskie Studia Historyczno-Teologiczne 23/24 (199-91), s. 62-83.
} 
dyspensą od formy kanonicznej, w przypadku osób występujących z Kościoła, oddalony zostaje zarzut o braku poszanowania ius connubii czy zasad wolności religijnej ${ }^{83}$.

\section{Zakończenie}

W podsumowaniu artykułu należy stwierdzić, dawne i aktualne przepisy prawa kanonicznego przy zawieraniu małżeństwa mieszanego sankcjonują zakaz. Jest on motywowany przede wszystkim trudnościami w istotnych sferach, jakie z dużym prawdopodobieństwem mogą napotkać małżonkowie, których dzielą różnice wyznaniowe. Potencjalne trudności, z jakimi muszą się zmierzyć małżonkowie, to przede wszystkim: rozbieżności w pojmowaniu małżeństwa, niebezpieczeństwo indyferentyzmu religijnego, zagrożenie wierności względem własnego Kościoła, utrudnienie praktyki wiary i trudność w religijnym wychowaniu potomstwa. Kościół udziela zezwolenia na zawarcie tego rodzaju małżeństwa, jeśli istnieje słuszna i rozumna przyczyna oraz wykluczone zostaje realne niebezpieczeństwo utraty wiary katolickiej przez katolickiego małżonka, a także zagwarantowanie jego prawa w odniesieniu do praktykowania wiary i wychowania potomstwa. Nadto daje także możliwość dyspensowania od formy kanonicznej.

Z przeprowadzonego dyskursu wynika, że działalność ustawodawcza papieży Benedykta XVI i Franciszka miała wpływ na rozumienie kwestii związanych $\mathrm{z}$ formą $\mathrm{w}$ zawieranych małżeństwach mieszanych. $\mathrm{Z}$ uwagi na to, że osoby, które formalnym aktem wystąpiły z Kościoła nie mogą ważnie zawrzeć małżeństwa z osobą nieochrzczoną, poszerza się zakres podmiotowy przeszkody różności religii, czyli małżeństw mieszanych w szerokim tego słowa znaczeniu. Ponadto usunięcie z kanonu 1124 KPK klauzuli actus formalis defectionis ab Ecclesia Catholica tym samym poszerza krąg osób, które są związane przepisami o małżeństwach mieszanych w sensie ścisłym. Z narracji wynika też, że konieczność zachowania formy kanonicznej przy zawieraniu małżeństw mieszanych jest wymogiem

${ }^{83}$ Por. R. Wierzchanowski, Czy jeszcze katolik?...., s. 297-301. 
wprowadzonym przez Ustawodawcę. Zobowiązanie to nie posiada charakteru bezwzględnego, ponieważ istnieje możliwość dyspensowania przy istnieniu poważnych trudności (kan.1127 \$2), ale nie w sytuacji gdy istnieje słuszna i racjonalna przyczyna.

W związku z motu proprio DCIC papieża Franciszka analiza $\$ 3$ kan. 1108 KPK w łączności z kan. 1127 uzasadnia, dlaczego tylko kapłan może asystować i błogosławić związek małżeński, gdy jedna strona przynależy do Wspólnoty wschodniej, wykluczając diakona i osobę świecką. Wyjaśnia się również znaczenie nowego $\$ 3$ kan. 1116 $\mathrm{w}$ formie nadzwyczajnej zawierania małżeństwa przy poszerzonych uprawnieniach katolickiego ordynariusza miejsca. W końcowej części podejmuje się kwestie waloru prawnego i funkcji formy zawarcia małżeństwa w kontekście aktu formalnego wystąpienia z Kościoła.

Z rozważań wynika, iż ostateczną racją formy kanonicznej jest wymóg poznawalności sakramentalnego znaku małżeństwa i zniesienie obowiązku zachowania formy kanonicznej ad validitatem matrimonii nie znajduje wystarczającego uzasadnienia, gdyż wprowadziłoby to więcej zamieszania i wątpliwości niż potencjalnych korzyści. Natomiast godna uwagi jest propozycja de lege ferenda. Można także wyrazić nadzieję, że nowa Instrukcja Konferencji Episkopatu Polski przyczyni się też do adekwatniejszych rozwiązań prawnych co do samych małżeństw mieszanych i ich formy zawierania.

\section{Form of a mixed marriage}

The article is an attempt to show the form of entering into a mixed marriage in the context of changes in canonical marriage law and the possibility of dispensation from form. The new $\$ 3$ can. 1108 of KPK in communication with can.1127 and justifies why only a priest can assist and bless marriage when one party belongs to the Eastern Community, excluding a deacon and a lay person, and an attention is paid to entities that can grant a dispensation. The meaning of the new $\$ 3$ can. 1116 is also explained in the form of an extraordinary marriage with the extended rights of the Catholic ordinary of the place. In the final part, the issue of legal value and the function of 
the form of marriage in the context of the formal act of leaving the Church are being addressed.

SŁOWA KLUCzowE: małżeństwo mieszane; dyspensowanie od formy; zmiana prawa; De Concordia inter Codice; Omnium in mentem; formalny akt wystąpienia z Kościoła; walor formy kanonicznej

KEYWORDS: mixed marriage; dispensation from form; change of law; De Concordia intern Codice; Omnium in mentem; formal act of withdrawal from the Church; the value of canonical form

\section{Nota o Autorze:}

Ks. PROF. DR hab. Henryk Stawniak SDB - prof. zw. nauk prawnych $\mathrm{w}$ dyscyplinie prawa kanonicznego, pracownik naukowo-dydaktyczny UKSW w Warszawie, kierownik Katedry Kanonicznego Prawa Małżeńskiego i Rodzinnego, kierownik Zakładu Prawa Małżeńskiego, wykładowca w Salezjańskim Wyższym Seminarium Duchownym w Krakowie, autor licznych opracowań z materialnego i procesowego prawa małżeńskiego. 